\title{
A 12-year-old boy presented with jaundice, abdominal distension and leg edema
}

\author{
Md. Benzamin, Rafiqul Islam, Nahid-E-Subha and Fahmida Begum
}

\begin{abstract}
Article Info
Department of Pediatric Gastroenterology and Nutrition, Faculty of Pediatrics, Bangabandhu Sheikh Mujib Medical

University, Shahbag, Dhaka, Bangladesh

For Correspondence:

Md. Benzamin

drmd.benzamin@yahoo.com

Received:

Accepted:

Available Online:

24 December 2019 18 February 2020 19 February 2020

ISSN: 2224-7750 (Online) 2074-2908 (Print)

DOI: 10.3329/bsmmuj.v13i1.45045

Keywords: Abdominal distension; Edema; Hepatitis; Jaundice; Wilson's disease

Cite this article:

Benzamin $M$, Islam $R$, Nahid-E-Subha, Begum F. A 12-year-old boy presented with jaundice, abdominal distension and leg edema. Bangabandhu Sheikh Mujib Med Univ J. 2020; 13: 22-26

Copyright:

The copyright of this article is retained by the author(s) [Atribution CC-By 4.0]

Available at:

www.banglajol.info
\end{abstract}

A Journal of Bangabandhu Sheikh Mujib Medical University, Dhaka, Bangladesh
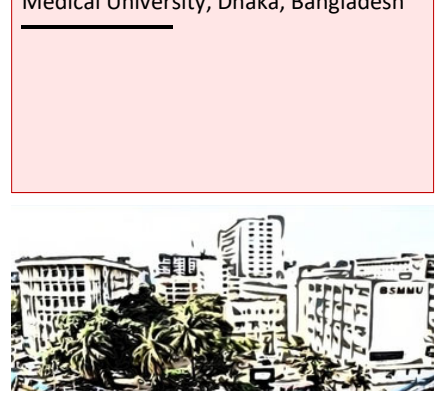

\section{Differential Diagnosis}

Dr. Rafiqul Islam (Resident): As chronic hepatitis $B$ in Bangladesh is not uncommon, we differentially thought about chronic liver disease due to HBV infection with portal hypertension.

\section{Chronic liver disease}

Dr. Kaniz Fathema (Resident): Chronic liver disease in childhood is characterized by the development of cirrhosis and its complications, and by progressive hepatic failure. 1 Chronic liver disease can be either compensated or decompensated. In compensated liver disease, the liver is still able to carry out most or all of its functions. 2 There are no clinical features of liver failure. The compensated liver disease will eventually progress to decompensated liver disease. In decompensated liver disease, the clinical and laboratory findings are consistent with the liver synthetic failure. Patients have hepatic dysfunction and cholestasis, leading to malnutrition, coagulopathy, impaired protein synthesis, portal hypertension, ascites, hepatopulmonary syndrome, hepatorenal syndrome, and hepatic encephalopathy. - It may present with hepatic hydrothorax.

\section{Hepatitis $B$}

Dr. Benzamin: $\mathrm{HBV}$ is a circular, partially double-stranded DNA hepatotropic virus, member of the hepadnaviridae. Transmission occurs through the mucosal or percutaneous exposure to infected blood or body fluids. Nonsexual transmission may occur in extended interpersonal contact with chronic hepatitis B infection. $\frac{5}{2}$ The prevalence in Southeast Asia is 2\%.6 Hepatitis B infection may present with features acute hepatitis, anicteric hepatitis, acute liver failure, chronic liver disease with or without complication. 7 Chronic Hepatitis B infection evolves through five phases. All patients may not experience all phases and phases may not be sequential. The duration of phases varies and reversion of phases may occur. Phases are: a) immune tolerant phase, b) immune reactive phase, $c$ ) inactive carrier state, d) $\mathrm{HBeAg}$ negative $\mathrm{CHB}$ phase, and e) $\mathrm{HBsAg}$ negative phase. $\underline{8}$

\section{Wilson's disease}

Dr. Rafiq: Wilson's disease is a copper storage disease.9 It results from the accumulation of 


\begin{tabular}{|c|c|c|}
\hline \multicolumn{3}{|c|}{ Table I } \\
\hline \multicolumn{3}{|c|}{ Laboratory Investigations } \\
\hline Investigations & Results & Referrence \\
\hline Hemoglobin $(\mathrm{gm} / \mathrm{dL})$ & 11 & $13-17$ \\
\hline White blood cells $\left(/ \mathrm{mm}^{3}\right)$ & 6000 & $4500-5500$ \\
\hline Platelet $\left(/ \mathrm{mm}^{3}\right)$ & 60000 & $150000-450000$ \\
\hline Peripheral blood flim & Thrombocytopenia & \\
\hline Serum albumin (g/dL) & 1.9 & 3.5-5.5 \\
\hline Serum bilirubin (mg/dL) & 8.6 & $0.2-1.2$ \\
\hline Prothrombin time (sec) & 26 & $12-16$ \\
\hline International normalized ratio & 2.1 & $<1.4$ \\
\hline $\begin{array}{l}\text { Serum alanine aminotranseferase } \\
(\mathrm{U} / \mathrm{L})\end{array}$ & 121 & $35-50$ \\
\hline Serum electrolytes (mmol/L) & $\begin{array}{r}\mathrm{Na}^{+} 136 \\
\mathrm{~K}^{+} 3.6 \\
\mathrm{Cl}^{-} 101\end{array}$ & $\begin{array}{r}136-145 \\
3.5-4.5 \\
98-107\end{array}$ \\
\hline Urine $\mathrm{R} / \mathrm{M} / \mathrm{E}$ & Normal & \\
\hline Serum creatinine $(\mathrm{mg} / \mathrm{dL})$ & 0.45 & $0.42-0.71$ \\
\hline Serum ceruloplasmin $(\mathrm{mg} / \mathrm{dL})$ & 5 & $>20$ \\
\hline 24-hour urinary copper (mcg/day) & 659 & $<40$ \\
\hline $\begin{array}{l}\text { Eye evaluations for K-F ring, sun- } \\
\text { flower cataract present }\end{array}$ & Present & \\
\hline HBsAg & Negative & \\
\hline Anti-HCV & Negative & \\
\hline
\end{tabular}

toxic levels of copper mainly in the liver and secondarily in other organs such as the kidneys, brain, and cornea. 10 The disease is caused by a mutation in the ATP7B gene.11 Clinical manifestations range from asymptomatic, with or without raised transaminases to chronic liver disease with complication with or without neurological involvement. $\underline{12-14}$

Dr. Benzamin: After evaluating patient's physical findings and laboratory test results, he was further evaluated with HBsAg and anti-HCV, which was normal. Therefore, chronic viral hepatitis was excluded. The endoscopy of upper gastrointestinal tract shows grade II varices.

Dr. Rafiq: To reach the diagnosis of Wilson's disease, we did the following and the findings were: serum ceruloplasmin level was low $(5 \mathrm{mg} / \mathrm{dL}), 24$ hours urinary copper level was high ( $659 \mathrm{mcg} / 24$ hour), slit lamp examination of eye showed K-F ring and sunflower cataract.

\section{Dr. Benzamin's Diagnosis}

Chronic liver disease due to Wilson's disease with portal hypertension (grade II varices)
We treated the case with low copper diet, zinc (25 $\mathrm{mg}$ thrice daily), D-penicillamine $(20 \mathrm{mg} / \mathrm{kg} /$ day $)$ and propranolol ( $1 \mathrm{mg} / \mathrm{kg} /$ day).

\section{Discussion}

Dr. Fahmida Begum (Associate Professor): Wilson's disease is an autosomal recessive disease. 9 ATP7B gene codes for a protein facilitates the incorporation of copper into apoceruloplasmin to form ceruloplasmin and also the transportation of copper into vesicles that allow it to be secreted in bile. The critical effect of a mutation in ATP7B is decreased secretion of ceruloplasmin into blood and decrease in excretion of copper into bile, which results in the accumulation of toxic levels of copper in different organs. $\underline{15}$ Incidence is 1:30,000 live births and the carrier frequency is approximately 1 in 90 internationally. $\underline{16}$ This disease may present at any age from infancy (with raised transaminases, measured for some unrelated reason) to the eighth decade.12,17 Prior to age 10 years, $83 \%$ presented with hepatic symptoms and $17 \%$ with neuropsychiatric manifestations. At $10-18$ years, $52 \%$ presented with hepatic and $48 \%$ with neuropsychiatric symptoms. 18,19 Clinical features include asymptomatic, with or without raised transaminases which may discovered serendipitously or detected during screening of family members. Hepatic presentation include Incidental finding of hepatomegaly, insidious onset of vague symptoms followed by jaundice, acute hepatitis, acute liver failure with haemolysis, chronic hepatitis, steatohepatitis, gallstones, portal hypertension, decompensated cirrhosis and hepatocellular carcinoma. Neurological and neuropychiatric features developed in second decade and later. Due copper deposition in eye KF rings and sunflower cataract may found. Coombs negative acute hemolytic anemia, renal tubular dysfunction (Fanconi, RTA, amino aciduria), renal calculi, rickets/osteomalesia, amenorrhea and hyperpigmentation also found.12-14

Dr. Nayeema Rahman (Resident): How do the Wilson's disease diagnosed?

Dr. Nahid-E-Subha (FCPS student): Wilson's disease is diagnosed by using modified Leipzig score. On scoring system, highest score is 17; score 4 or more is diagnostic for Wilson's disease. $\underline{20}$

Dr. Kaniz Fathema (Resident): What will be the explanation of Wilson's disease in baby of nonconsanguineous and having normal genetic study parents?

Dr. Benzamin: Wilson's disease in baby of nonconsanguineous and having normal genetic study parents may occur due to new mutation of ATPB7 gene. .11

Dr. Maimuna Sayeed (Resident): What will be the 
dietary changes in your patient?

Dr. Islam: Dietary management is important for Wilson's disease. Very high copper containing food (shellfish, nuts, chocolate, mushrooms, and organ meats) generally should be avoided. Diets deficient in copper may delay the onset of the disease and control disease progression. A high protein diet should be consumed because the increased excretion of amino acids can increase urinary copper excretion. $.14,22$

Dr. Kamrun Nahar (Resident): What is the pathognomic eye findings in Wilson's disease?

Dr. Benzamin: Sunflower cataract is the pathognomic eye findings in Wilson's disease. KF rings can found in other's condition like chronic cholestasis disorder such as partial biliary atresia, primary biliary cirrhosis, primary sclerosing cholangitis and cryptogenic cirrhosis. $.23,17$

Dr. Urmi Roy (Resident): What are the other condition where ceruloplasmin may be low?

Dr. Islam: Low ceruloplasmin level may found in protein deficiency states like -nephrotic syndrome, malabsorption, protein losing enteropathy, malnutrition and acute liver failure of any etiology. $\underline{\underline{24}}$

Dr. Nazmul Hossain (Resident): What is K-F ring?

Dr. Subha: Kayser-Fleischer (K-F) ring, a greenishbrown ring at the periphery of the cornea on its posterior surface in Descemet's membrane due to depositioned layers of copper granules. The K-F ring initially appears at the superior poles of the cornea, with subsequent involvement of inferior poles followed by circumferential involvement. 17

Dr. Saidul Islam (Resident): At which early age the Wilson's disease can be diagnosed?

Dr. Benzamin: It may present at any age from infancy with raised transaminases, measured for some unrelated reason. The clinical presentation is rare below three years. In case of neonate, it can be diagnosed by genetic testing. $\underline{.14}$

Dr. Safiul Alam (Resident): What are the neurological features observed?

Dr. Islam: The neurological and pychiatric features are usually seen in the second decade and later. Feautres include tremor (resting, intention), drooling, hypersalivation, dysarthria, coordination defects, clumsiness, dystonia, writing difficulties, choreiform movements, ataxic gait, fixed grin, headache, seizures, organic dementia, neuroses, anxiety, depression, obsessive/compulsive disorder, schizophrenia, bipolar disorder and antisocial behavior etc. $\underline{14,24,25}$

Dr. Parisa Marjan (Resident): Is it necessary to do liver biopsy for the diagnosis of Wilson's disease?

Dr. Subha: Measurement of liver copper content is recommended in equivocal case. A copper content $\geq 250 \mathrm{mg} / \mathrm{g}$ dry weight (normal $<50 \mathrm{mg} / \mathrm{g}$ dry weight) in non-cholestatic patient is considered the diagnostic for Wilson's disease in adult.24 Liver biopsy also done to see the hepatic content of copper per gram dry weight liver tissue and staining of the liver tissue with Orcein- or Rhodanine. 20 But these investigations are not available in our country. If the other criteria are enough to diagnose the Wilson's disease, there is no need of liver biopsy.

Dr. Mukesh Khadga (Resident): What is the role of zinc and when to take in relation to meal?

Dr. Benzamin: Zinc acts by induction of metallothionein in enterocytes, which sequesters copper, and renders it nontoxic. Copper absorbed from the small intestine is, thereby, sequestered in enterocytes which at the end of their life cycle carry copper into the lumen. Zinc also induces hepatocyte metallothionein, detoxify liver copper. Zinc should be given 1 hour before meal or 2 hours after meal. $\underline{24}$

Dr. Mohammad Ahmadur Rahman (Resident): How does penicillamine act and when to take in relation to meal?

Dr. Islam: Penicillamine acts by inducing hepatic metallothionein, a cytosolic metal-binding protein which sequesters copper, and renders it nontoxic and excrete through the urine. It is given 1 hour before meal or 2 hours after meal apart from zinc. 24

Dr. Ayesha Siddiqua (Resident): What are the side effects of zinc and penicillamine?

Dr. Subha: Zinc has a few adverse effects like gastric irritation, asymptomatic elevation of serum amylase and lipase. The neurological deterioration is described but very uncommon. $14,20,24$

Several adverse effects may observe on penicillamine therapy. Early adverse effects include hypersensitivity, fever, cutaneous eruptions, lymphadenopathy, neutropenia, thrombocytopenia, and proteinuria. Late adverse effects include hypersensitivity, lupus-like syndrome (proteinuria, hematuria, positive ANA), good pasture syndrome, severe thrombocytopenia, total aplasia of bone marrow, optic neuritis, nephrotoxicity, myasthenia gravis, polymyositis, pyridoxine deficiency. Neurological deterioration may occur. The incidence ranges from 10 to $50 \% . \underline{14,20,24}$

Dr. Nyema Rahman (Resident): How will you followup the patient?

Dr. Benzamin: Patient will be regularly monitored for ensuring compliance, efficacy of therapy, and early recognition of adverse effects. The clinical improvement is characterized by decreasing jaundice, ascites, and portal hypertension. Effective decoppering is assessed on 24-hour urine copper and serum free copper value. This is initially done 
after a month, then 3 monthly, and subsequently 612 monthly. For biochemical recovery and to see the adverse effects of drug: Complete blood counts, urine analyses, liver function tests (serum aminotranferases, Gama GT, prothrombin time), are performed initially after a week, then at 2 and 4 weeks followed by 3, 6 months, and then yearly. KF ring should be evaluated annually.20

Dr. Ruhina Tasmeen (Research Assistant): How K-F ring disappear in response to treatment?

Dr. Islam: Chelation therapy causes the disappearance of rings in 3-5 years in the reverse order of appearance. $.20,24$

Dr. Dipannita: How will you do the family screening and why?

Dr. Benzamin: All first-degree relatives of a patient with newly diagnosed Wilson's disease should screen. Probability of finding a homozygote in siblings is $25 \%$. Investigations for screening include serum alanine aminotranseferase, serum caeruloplasmin and 24-hours urinary copper excretion. 26,27

Dr. Nahid-E-Subha (Resident): What will be the treatment of asymptomatic Wilson's disease?

Dr. Islam: All asymptomatic Wilson's disease should be treated to prevent symptomatic disease. Zinc is the drug of choice, because it is more physiologic and less toxic. For neonate discovered on genetic testing treatment should not be start in the first year. Starting at the age of 2 years is a defensible. $\underline{14}$

Dr. Ayesha Sabiha (Resident): What will be prognosis?

Dr. Subha: Early diagnosis and good adherent to treatment ensure good outcome. Usually the liver function improved after chelation therapy, even in the chronic liver disease patient. This patient was symptomatically improved after initial therapy. But as the patient having decompensate chronic liver disease with portal hypertension, long-term outcome is poor. 20

\section{Follow-up}

The child was improved clinically (ascites and edema resolved) but coagulopathy (INR 1.8), raised serum alanine aminotranseferase $(86 \mathrm{U} / \mathrm{L})$, serum bilirubin $(4.6 \mathrm{mg} / \mathrm{dL})$ were persisting on 1 month of treatment and then further treatment continued accordingly.

\section{Final Diagnosis}

Chronic liver disease due to Wilson's disease with portal hypertension (grade II varices)

\section{Conflict of Interest}

The authors declare no conflict of interest.

\section{Acknowledgement}

We are grateful to Dr. Gopen Kumar Kundu, Associate Professor, Department of Pediatric Neurology and Neurodevelopment, Bangabandhu Sheikh Mujib Medical University, Dhaka, Bangladesh for neurological evaluation.

\section{References}

1. Kliegman RM, Marcdante KJ. Liver disease. In: Nelson essential of pediatrics. $8^{\text {th }}$ edn. Philadelphia, Elsevier Inc, 2019, pp 494-501.

2. Mileti E, Rosenthal P. Liver failure and portal hypertension. In: Pediatric practice gastroenterology. Bishop WP (ed). New York, McGraw-Hill Companies Inc, 2010, pp 417-23.

3. Hsu EK, Murray FK. Cirrhosis and chronic liver failure. In: Liver disease in children. Suchy FJ, Sokol RJ, Balistreri WF (eds). $4^{\text {th }}$ ed. Cambridge, Cambridge University Press, 2014, pp 51-67.

4. Marjan $\mathrm{P}$, Rukunuzzaman M, Karim ASMB, Mondal M, Akter H. A 9-year-old girl presented with jaundice, abdominal distension, hematemesis, melena and pleural effusion. Bangabandhu Sheikh Mujib Med Univ J. 2018; 11: 300-03.

5. Chang MH. Infections: Hepatitis $\mathrm{B}$ virus. In: Walker's pediatric gastrointestinal disease. Kleinman RE, Goulet OJ, Mieli-Vergani G, Sanderson IR, Sherman MP, Shneider BL (eds). $6^{\text {th }}$ ed. North Carolina, People's Medical Publishing House, 2018, pp 3257-93.

6. World Health Organization. Global hepatitis report. Geneva, 2017, pp 1-62.

7. Romero JR, O'Connor JA. Viral hepatitis. In: Pediatric practice gastroenterology. Bishop WP (ed). New York, McGraw-Hill Companies Inc, 2010, pp 341-55.

8. Rukunuzzaman $\mathrm{M}$, Benzamin $\mathrm{M}$, Sultana $\mathrm{K}$. Management of chronic HBV infection in children. In: Viral hepatitis: Chronic hepatitis B. Ozaras R, Tahan V (eds). Cham, Springer, 2018, pp 11-23.

9. Reilly M, Daly L, Hutchinson M. An epidemiological study of Wilson's disease in the Republic of Ireland. J Neurol Neurosurg Psychiatry. 1993; 56: 298-300.

10. Sherlock S, Dooley J. Wilson's disease. In: Diseases of the liver and biliary system. 11th ed. Oxford, Blackwell Science, 2002, pp 413-22.

11. Bandmann O, Weiss KH, Kaler SG. Wilson's disease and other neurological copper disorders. Lancet Neurol. 2015; 14: 103-13. 
12. Ferenci P, Caca K, Loudianos G, Mieli-Vergani G, Tanner S, Sternlieb I, Schilsky M, Cox D, Berr F. Diagnosis and phenotypic classification of Wilson's disease. Liver Int. 2003; 23: 139-42.

13. Rukunuzzaman M. Wilson's disease in Bangladeshi children: Analysis of 100 cases. Pediatr Gastroenterol Hepatol Nutr. 2015; 18: 121-27.

14. Socha P, Tanner S. Genetic and metabolic disorders: Wilson's disease. In: Walker's pediatric gastrointestinal disease. Kleinman RE, Goulet OJ, Mieli-Vergani G, Sanderson IR, Sherman MP, Shneider BL (eds). $6^{\text {th }}$ ed. North Carolina, People's Medical Publishing House-USA, 2018, pp 39954049 .

15. Schilsky M, Tavill AS. Wilson's disease. In: Disease of the liver. Schiff ER et al (eds). 9 $9^{\text {th }}$ ed. Philadelphia, Lippincott Williams \& Wilkins, 2003, pp 1169-86.

16. Liu J, Luan J, Zhou X, Cui Y, Han J. Epidemiology, diagnosis, and treatment of Wilson's disease. Intractable Rare Dis Res. 2017; 6: 249-55.

17. Patil M, Sheth KA, Krishnamurthy AC, Devarbhavi H. A review and current perspective on Wilson's disease. J Clin Exp Hepatol. 2013; 3: 321-36.

18. Walshe JM. The liver in Wilson's disease (hepatolenticular degeneration). In: Diseases of the liver. Schiff L, Schiff ER (eds.) Philadelphia, Lippincott, 1982, pp 1037-50.

19. Sokol RJ, O'connor JA. Copper metabolism and copper storage disorders. In: Liver disease in children. Suchy FJ, Sokol RJ, Balistreri WF (eds). 3rd ed. New York, Cambridge University Press, 2007, pp 626-52.

20. Nagral A, Sarma MS, Matthai J, Kukkle PL, Devarbhavi H, Sinha S, Alam S, Bavdekar A, Dhiman RK,
Eapen CE, Goyal V, Mohan N, Kandadai RM, Sathiyasekaran M, Poddar U, Sibal A, Sankaranarayanan S, Srivastava A, Thapa BR, Wadia PM, Yachha SK, Dhawan A. Wilson's Disease: Clinical practice guidelines of the Indian National Association for study of the liver, the Indian society of pediatric gastroenterology, hepatology and nutrition, and the movement disorders society of India. J Clin Exp Hepatol. 2019; 9: 74-98.

21. Davies LP, Macintyre G, Cox DW. New mutations in the Wilson's disease gene, ATP7B: Implications for molecular testing. Genetic Test. 2018; 12: 139-45.

22. Brewer GJ, Yuzbasiyan-Gurkan V, Dick R, Wang Y, Johnson V. Does a vegetarian diet control Wilson's disease? J Am Coll Nutr. 1993; 12: 527-30.

23. Litwin T, Langwińska-Wośko E, Dzieżyc $K$, Członkowska A. Sunflower cataract: Do not forget Wilson's disease. Pract Neurol. 2015; 15: 385-86.

24. Socha P, Janczyk W, Dhawan A, Baumann U, D'Antiga L, Tanner S, Iorio R, Vajro P, Houwen R, Fischler B, Dezsofi A, Hadzic N, Hierro L, Jahnel J, McLin V, Nobili V, Smets F, Verkade HJ, Debray D. Wilson's disease in children: A position paper by the hepatology committee of the European Society for Paediatric Gastroenterology, Hepatology and Nutrition. J Pediatr Gastroenterol Nutr. 2018; 66: 334-44.

25. Das SK, Ray K. Wilson's disease: An update. Nat Clin Pract Neurol. 2006; 2: 482-93.

26. Roberts EA, Schilsky ML. Diagnosis and treatment of Wilson's disease: An update. Hepatology 2008; 47: 2089-111.

27. Kathawala M, Hirschfield GM. Insights into the management of Wilson's disease. Therap Adv Gastroenterol. 2017; 10: 889-905. 